Sains Malaysiana 49(7)(2020): 1697-1712

http://dx.doi.org/10.17576/jsm-2020-4907-20

\title{
Gold Nanoparticles Biosynthesized using Lignosus rhinocerotis Extracts: Comparative Evaluation of Biostatic and Cytotoxicity Effects
}

(Nanozarah Emas Biosintesis menggunakan Ekstrak Lignosus rhinocerotis: Penilaian Perbandingan Kesan Biostatik dan Kesitotoksikan)

\author{
Ahmad Yasser Hamdi Nor Azlan, Haliza Katas*, Nur QAisara Jalluddin \& Mohd Fauzi Mh BusRa
}

\section{ABSTRACT}

Gold nanoparticles (AuNPs) are a unique class of nanomaterials applied in biomedical applications. Biological synthesis or biosynthesis of AuNPs offers advantages including simple and cost-effective method as well as nontoxic to human, making it superior to chemical synthesis. In this study, comparative evaluation was conducted for antimicrobial and cytotoxicity effects of chemically synthesized (Chem-AuNPs) and biosynthesized AuNPs (Bio-AuNPs). Chem- and Bio-AuNPs were produced using sodium citrate and L. rhinocerotis extracts, respectively. Different methods namely hot and cold-water extraction (HWE and CWE, respectively) were used to extract L. rhinocerotis sclerotium, a medicinal mushroom. Both types of nanoparticles were stabilized using chitosan (CS) and characterized for their physical characteristics, followed by determination of antibacterial and cytotoxicity effects in vitro. Formation of AuNPs exhibited surface plasmon resonance (SPR) band at 465-564 nm and 523-544 nm for Chem-AuNPs and BioAuNPs, respectively, as determined by UV-vis spectroscopy. CS-stabilized AuNPs had larger size of particles than nonstabilized ones, ranging from 200 to $500 \mathrm{~nm}$. Both Chem- and Bio-AuNPs showed biostatic activity against Grampositive bacteria (Bacillus sp. and Staphylococcus aureus) and Gram-negative bacteria (Pseudomonas aeruginosa and Escherichia coli). The cytotoxicity assay for 24 h showed higher cell viability for Bio-AuNPs than Chem-AuNPs, indicating relatively less toxicity of Bio-AuNPS. In conclusion, Bio-AuNPs using the mushroom extracts and CS provide opportunities for developing stable, safer, and eco-friendly nanoparticles with effective antibacterial properties for clinical applications.

Keywords: Antibacterial effect; cytotoxicity; green synthesis; metal nanoparticles; nanocomposites

\section{ABSTRAK}

Nanozarah emas (AuNPS) merupakan satu kelas bahan nano yang unik, digunakan dalam aplikasi bioperubatan. Sintesis secara biologi atau biosintesis AuNPs menawarkan kelebihan termasuk kaedah sintesis yang mudah dan kos-efektif serta tidak bertoksik kepada manusia, menjadikan kaedah ini lebih unggul berbanding sintesis kimia. Dalam kajian ini, penilaian secara perbandingan telah dilakukan untuk kesan antimikrob dan kesitotoksikan terhadap AuNPs yang dihasilkan secara kimia (Chem-AuNPs) dan biologi (Bio-AuNPs). Chem-dan Bio-AuNPs dihasilkan masing-masing menggunakan natrium sitrat dan ekstrak L. rhinocerotis. Kaedah berbeza iaitu pengekstrakan air panas dan sejuk (masing-masing diringkaskan sebagai HWE dan CWE) telah digunakan untuk mengekstrak sklerotium L. rhinocerotis iaitu sejenis cendawan bernilai perubatan. Kedua-dua jenis nanozarah ini telah distabilkan menggunakan kitosan (CS) dan ditentukan ciri-ciri fizikal nanozarah yang terhasil, diikuti dengan penentuan kesan antibakteria dan kesitotoksikan secara in vitro. Pembentukan AuNPs memperlihatkan jalur resonans plasmon permukaan (SPR) pada 465-564 nm dan 523-544 nm, masing-masing untuk Chem-dan Bio-AuNPs yang ditentukan menggunakan spektroskopi UV. AuNPs yang distabilkan oleh CS mempunyai saiz zarah yang lebih besar berbanding AuNPs yang tidak distabilkan, dengan saiz zarah antara 200 hingga 500 nm. Kedua-dua Chem-dan Bio-AuNPs menunjukkan kesan biostatik terhadap bakteria gram-positif (Bacillus sp. dan Staphylococcus aureus) dan bakteria gram-negatif (Pseudomonas aeruginosa dan Escherichia coli). Ujian kesitotoksikan selama 24 jam menunjukkan daya kehidupan sel yang lebih tinggi untuk Bio-AuNPs berbanding Chem-AuNPs, membuktikan Bio-AuNPs adalah kurang toksik secara relatif. Kesimpulannya, Bio-AuNPs yang dihasilkan menggunakan ekstrak cendawan dan CS menyediakan peluang untuk membangunkan nanozarah yang stabil, lebih selamat dan mesra alam dengan sifat antibakteria yang berkesan untuk aplikasi klinikal.

Kata kunci: Kerintangan antibiotik; kesitotoksikan; nanokomposit; nanozarah logam; sintesis hijau 


\section{INTRODUCTION}

The rising of antimicrobial resistance to pathogenic bacteria is a significant threat to human health. Recently, the Center for Disease Control (CDC) has declared that the 'post-antibiotic era' (Control \& Prevention 2019) is about to struck the world, by which bacterial infections cause more death than cancer and the existing drugs can no longer perform miracles. This has led to the search of new antibiotics and the application of nanotechnology is one of the promising approaches to address the problem. Metallic nanoparticles such as gold and silver are known to exhibit antimicrobial activity and are used to combat infections, including those that are resistant to existing antibiotics (Shahzadi et al. 2018). Gold nanoparticles (AuNPs) have been successfully developed as new antibacterial agents and in comparison, to silver nanoparticles, AuNPs were less toxic (Asharavani et al. 2010). Large surface area of AuNPs alongside surface functionalization with other molecules has allowed the development of versatile AuNPs with enhanced antibacterial activity (Alaqad \& Salleh 2016).

Metallic nanoparticles can be produced by physical and chemical methods (Ishak et al. 2019; Katas et al. 2018). More recently, many studies have explored ways to produce metallic nanoparticles using biology method or green synthesis, reported to be environmentally friendly approaches (Ahmed et al. 2019; Sulaiman et al. 2013). Despite chemical synthesis produces very small AuNPs particles $(\sim 4 \mathrm{~nm})$, the particles however, are poorly stable (Ojea-Jiménez et al. 2010). The use of toxic materials in chemical synthesis also increases the risk of adverse effect to human beings. Therefore, the application of natural sources has received great interests as an alternative to the chemical approach (Shankar et al. 2004).

Biosynthesis is a non-toxic approach for synthesizing AuNPs with high catalytic activity and specific surface area (Chokriwal et al. 2014). In this approach, natural sources such as plants (Kaviya 2017) and microorganisms (Pantidos \& Horsfall 2014) had been used as reducing agents, reducing gold ions into nanoparticles. Recently, Lignosus rhinocerotis extracts have been reported to reduce gold ions into AuNPs (Katas et al. 2019). In the study, LC-MS of sclerotium of L. rhinocerotis extracts (LRE) (through cold water extraction (CWE) and hot water extraction (HWE)) showed high contents of polysaccharides, oligosaccharides, fatty acids and phenols, potentially acted as reducing agents and the resultant AuNPs exhibited enhanced antibacterial activity (Katas et al. 2018). The mushroom has also been successfully cultivated for commercialization, allowing the use of its extract for the development of AuNPs as an antibacterial agent.

Stabilizing agent is widely used in the production of metallic nanoparticles to prevent aggregation (Hussain et al. 2015). Chitosan (CS) and its derivatives have been used as reducing and stabilizing agents for synthesizing stable AuNPs (Nazirov et al. 2016). CS as stabilizing agent is affordable and environmentally friendly, making it suitable for green synthesis. CS is also non-toxic and biodegradable and thus, it has been extensively used for improving biocompatibility of metallic nanoparticles (Bonardd et al. 2016).

In this study, comparative evaluation was carried out for physical characteristics, antibacterial, and cytotoxicity effects of chemically synthesized (Chem-AuNPs) and biosynthesized AuNPs (Bio-AuNPs). Chem-AuNPs were produced using sodium citrate (a well-known method developed by Turkevich and French) while, BioAuNPs were produced using LRE, by HWE, and CWE. Both Chem- and Bio-AuNPs were stabilized using CS and characterized for their physical characteristics, followed by determination of their antibacterial activity against selected gram-positive and -negative bacteria and cytotoxicity effect in vitro.

\section{MATERIALS AND METHODS}

\section{MATERIALS}

Gold (III) chloride hydrate (99.999\% trace metals basis) was purchased from Sigma-Aldrich (Malaysia). Sodium citrate tribasic dihydrate was purchased from Sigma-Aldrich (Ireland). L. rhinocerotis sclerotial powder was provided as a gift from Lignas Bio Synergy Plt., Selangor, Malaysia. Low molecular weight (LMW) CS (molecular weight of $190 \mathrm{kDa}, 75-85 \%$ degree of deacetylation) was purchased from Sigma-Aldrich (Ireland). Glacial acetic acid (99.7\% purity) was purchased from R\&M Chemicals, UK. Distilled water was produced in the laboratory using Hamilton WCS/85 Cabinet Water Still.

For antibacterial test, four bacterial strains (Staphylococcus aureus ATCC 6538, Pseudomonas aeruginosa ATCC 9027, Bacillus sp. ATCC 27380 and Escherichia coli ATCC 25927) were obtained from Microbiology Laboratory of Faculty of Pharmacy, Universiti Kebangsaan Malaysia (Kuala Lumpur, Malaysia). Mueller-Hinton broth (MHB) and MuellerHinton agar (MHA) were obtained from Difco laboratory of Becton Dickinson Company, USA. Gentamicin sulfate was purchased from Nacalai Tesque, Japan. For cell viability test, human dermal fibroblasts (HDF) were isolated from human skin sample after obtaining consent from patient.

\section{METHODS}

\section{PREPARATION OF CHEM-AUNPS}

$2 \mathrm{~mL}$ of $0.1 \mathrm{M} \mathrm{HAuCl}_{4}$ solution was mixed with different concentrations of sodium citrate solution $(1,0.5,0.25$, 0.125 , or $0.0625 \mathrm{mg} / \mathrm{mL}$ ) to form non-stabilized AuNPs 
(w/o-AuNPs). The mixture was stirred continuously at 500 revolutions per minute (rpm) and heated at $40-65$ ${ }^{\circ} \mathrm{C}$ until a stable purplish-wine color was observed. To obtain stabilized AuNPs (w-AuNPs), 2 mL of 1\% LMW CS as a stabilizing/capping agent was added into the mixture (after purplish wine was formed) and stirred for $10 \mathrm{~min}$ continuously at the same temperature as mentioned previously. Both w/o- and w-AuNPs were left to cool at room temperature and stored at $4{ }^{\circ} \mathrm{C}$ refrigerator for further analysis.

\section{PREPARATION OF COLD AND HOT WATER LRE (CLRE AND HLRE, RESPECTIVELY)}

For HLRE, powdered sclerotium was boiled in distilled water at the ratio $1: 20(\mathrm{w} / \mathrm{v})$ at $90-95^{\circ} \mathrm{C}$ for $60 \mathrm{~min}$. Then, the mixture was filtered using Whatman No. 1 filter paper and the residues were re-extracted twice. For CLRE, a mixture of powdered sclerotium in water at the same ratio was continuously stirred at room temperature for 8 h. Then, the mixture was kept at $-20{ }^{\circ} \mathrm{C}$ overnight. The frozen mixture was left at room temperature until it melted completely prior to stirring for $8 \mathrm{~h}$, followed by keeping at $-10{ }^{\circ} \mathrm{C}$. This process was repeated thrice before the mixture was filtered using Whatman No. 1 filter paper and residues were re-extracted twice. The mixtures from HWE and CWE were then separately centrifuged at $10000 \mathrm{rpm}$ and freeze-dried using ScanVac CoolSafe Basic Freeze Dryer $\left(-110^{\circ} \mathrm{C}, 4 \mathrm{~L}\right)$. The resultant HLRE and CLRE were kept at $-20{ }^{\circ} \mathrm{C}$ prior to analysis. The extracts were fluffy powders with light and dark brown color for CLRE and HLRE, respectively.

\section{PREPARATION OF BIO-AUNPS USING LRE AND CS}

A solution of CLRE or HLRE at different concentrations $(0.0625,0.125,0.25,0.5$, and $1 \mathrm{mg} / \mathrm{mL})$ was mixed with $1 \mathrm{~mL} 0.1 \mathrm{M} \mathrm{HAuCl}_{4}$ solution. Meanwhile, $0.1 \mathrm{~g}$ of LMW CS was dissolved in $10 \mathrm{~mL}$ of $1 \% \mathrm{v} / \mathrm{v}$ acetic acid under magnetic stirring at $500 \mathrm{rpm}$ until fully dissolved. Subsequently, the mixture of extracts and $\mathrm{HAuCL}_{4}$ was mixed with CS solution. The mixture was then subjected to sonication. Approximately after $90 \mathrm{~min}$, a stable redpurplish-wine color was observed. The $\mathrm{pH}$ of AuNPs produced was adjusted from 6.8 to 7.4 , by adding $1 M$ sodium hydroxide. The AuNPs were cooled to room temperature prior to keeping at $5^{\circ} \mathrm{C}$ for further analysis.

\section{CHARACTERIZATION OF AUNPS} UV-VIS SPECTROPHOTOMETRIC

The formation of Bio- and Chem-AuNPs was determined by UV spectroscopy (UV-vis Shimadzu 1800 spectrophotometer, Japan). The scanning of samples was set from 300 to $700 \mathrm{~nm}$ at a scan speed of $480 \mathrm{~mm} /$ min. Baseline correction of the spectrophotometer was performed using a blank reference.

\section{ATR-FTIR SPECTROSCOPIC ANALYSIS}

Samples for Fourier transform infrared spectroscopyattenuated total reflectance (FTIR-ATR) were prepared by freeze drying the extracts, CS, sodium citrate and resulting Bio- and Chem-AuNPs. The FTIR-ATR spectra of samples were recorded on a FTIR spectrometer (Spectrum 100; PerkinElmer, Walthman, MA, USA). The spectra were acquired using 32 scans and a $4 \mathrm{~cm}^{-1}$ resolution from 4000 to $650 \mathrm{~cm}^{-1}$.

\section{PARTICLE SIZE, POLYDISPERSITY INDEX (PDI), AND ZETA POTENTIAL}

The mean particle size (Z-average), PDI and zeta potential (surface charge) of Bio- and Chem-AuNPs were measured by a ZS-90 Zetasizer (Malvern Instruments, Worcestershire, UK). All measurements were performed at $25^{\circ} \mathrm{C}$ at a detection angle of $90^{\circ}$. Each sample was measured in triplicate and the data were reported as mean \pm standard deviation (SD).

ANTIBACTERIAL ASSESSMENT

PREPARATION OF MUELLER HINTON (MH) AGAR PLATE

An amount of $19 \mathrm{~g}$ of Difco MH agar powder was diluted in $500 \mathrm{~mL}$ of purified distilled water. The mixture was then thoroughly mixed and heated until the powder was fully dissolved. The solution was transferred to Schott bottle of $1000 \mathrm{~mL}$ and autoclaved at $121^{\circ} \mathrm{C}$ for $20 \mathrm{~min}$. The sterile $\mathrm{MH}$ agar was poured onto sterile petri dishes and allowed to solidify prior to use.

\section{MH AGAR WELL DIFFUSION}

The antibacterial tests were performed using $\mathrm{MH}$ agar well diffusion method with selected four isolates of pathogenic bacteria: gram-positive bacteria $(S$. aureus ATCC 6538, Bacillus sp. ATCC 27380) and gram-negative bacteria ( $P$. aeruginosa ATCC 9027 and E. coli ATCC 25927). The tests were carried out under aseptic technique in a laminar flow biological safety cabinet (class II) BHA 120 (Clyde Apae). Briefly, three isolated single colonies of bacteria were picked out to prevent selecting an atypical variant. The organism then was suspended in $10 \mathrm{~mL}$ of $\mathrm{MH}$ broth. The suspension of bacteria was incubated for 24 $\mathrm{h}$ for growing. After $24 \mathrm{~h}$, the absorbance of the bacteria was measured using UV-vis spectroscopy. The turbidity of the suspension was standardized to McFarland 0.5 by adding more $\mathrm{MH}$ broth or bacteria. Once the bacteria suspension was standardized $\left(1-2 \times 10^{8} \mathrm{CFU} / \mathrm{mL}\right)$, a sterile cotton swab was dipped into the suspension. For gram-negative bacteria, the excess fluid was removed by pressing and turning the swab against the inner wall of the tube to avoid over-inoculation. Then, the inoculum was spread evenly without gaps between streaks over the entire surface by swabbing in three directions on MH agar plates. 
MH agar plates of each test organisms were prepared. The required numbers of holes (diameter $=6 \mathrm{~mm}$ ) were cut using a sterile $1000 \mu \mathrm{L}$ pipette tips. Different sterile pipette tips were used for different test organisms. Gentamicin $(1 \mathrm{mg} / \mathrm{mL})$ and Milli Q water was used as positive and negative control, respectively. Samples (70 $\mu \mathrm{L}$ of different concentrations of Bio- and Chem-AuNPs) were loaded into the holes separately. The lid was placed and sealed with parafilm before incubating (Memmert) at $37 \pm 0.2^{\circ} \mathrm{C}$. After $24 \mathrm{~h}$ of incubation, the diameter of inhibition zone $(\mathrm{mm})$ was measured using an electronic digital Vernier caliper. All the measurements were made with the unaided eyes while viewing the back of petri dish by holding the plate a few inches above a black, nonreflecting surface. The experiment was made in triplicate.

\section{DETERMINATION OF MINIMUM INHIBITORY \\ CONCENTRATION (MIC) AND MINIMUM BACTERICIDAL CONCENTRATION (MBC)}

MIC was calculated for the selected Bio-AuNPs only. From the selected nanoparticles, different concentrations of lyophilized Bio-AuNPs $(6.25,12.5,25,50,100$, and $200 \mu \mathrm{g} / \mathrm{mL}$ ) was prepared and determined for MIC using micro broth dilution method. The MIC is defined as the lowest concentration at which no visible cell growth is observed. The result was obtained by observation and absorbance reading using a microplate reader (Bio Tek PowerWave XS, US). Through microplate reader, point of MIC is where the level of absorbance of the well with treatment is lower than the well containing bacteria only. For determination of MBC, a sample from the first well with no visible growth was spread on the MH agar plates. $\mathrm{MBC}$ is stated as the concentration with maximum dilution displaying no growth on agar plates after $48 \mathrm{~h}$ incubation at $37^{\circ} \mathrm{C}$.

\section{CELL VIABILITY TEST}

In each well of 96-well plate, approximately 2500 cells/ well of HDF (cell passage number of 2-6) were seeded. The cells were grown in an incubator at $37^{\circ} \mathrm{C}$ with $5 \%$ $\mathrm{CO}_{2}$ overnight. Subsequently, the cells were exposed to various concentrations of Bio- and Chem-AuNPs $(0.0625,0.125,0.25,0.5$, and $1 \mathrm{mg} / \mathrm{mL})$ for $24 \mathrm{~h}$ at the treatment to growth media ratio of $1: 1$. After $24 \mathrm{~h}$, each well was then washed with sterile PBS solution before replacing with a fresh DMEM. Later, $10 \% \mathrm{w} / \mathrm{v}$ of alamarBlue ${ }^{\mathrm{TM}}$ solution was added to each well and further incubated for $4 \mathrm{~h}$. After that, the mixture in each well was transferred to a new 96-well plate before shaking on a shaker for $30 \mathrm{~min}$. The absorbance of the cell suspensions at $570 \mathrm{~nm}$ was recorded using a microplate reader (Bio Tek PowerWave XS, US). The percent of cell viability was calculated as follows:

Cell viability $(\%)=[($ absorbance of treated samples $) /($ absorbance of control)] $\times 100$

\section{STATISTICAL ANALYSIS}

Data obtained are presented as mean \pm standard deviation (SD). The data were analyzed by two-way ANOVA, followed by Bonferroni's test using GraphPad Prism 8 software. Values of $p<0.05$ indicated statistical significance difference among the groups tested.

\section{RESULTS AND DISCUSSION}

\section{FORMATION OF BIO-AUNPS AND CHEM-AUNPS}

In this study, AuNPs were formed by using chemical and biological synthesis. Different concentrations of reducing agent were used for CLRE as well as HLRE and sodium citrate for biosynthesis and chemical method, respectively. The reaction time for completing the formation of Bio-AuNPs was approximately $2 \mathrm{~h}$ while 15 to $20 \mathrm{~min}$ was recorded for Chem-AuNPs, by looking at the formation of purplish color, an indication of AuNPs in the reaction (Nayak 2014). Based on UV-vis spectroscopy analysis in Table 1(a) and 1(b), Bio- and Chem-AuNPs exhibited an absorption band around 523-544 and 466$564 \mathrm{~nm}$, respectively, a typical surface Plasmon resonance (SPR) band for AuNPs. The SPR band is originated from absorption photons and used to indicate the formation of AuNPs (Said et al. 2019). For AuNPs, the SPR band is reported within the range of 400-600 $\mathrm{nm}$ (Zhuang et al. 2018).

In case of Bio-AuNPs, the maximum wavelength increased as the concentration of HLRE or CLRE was increased from 0.0625 to $1.000 \mathrm{mg} / \mathrm{mL}$. By comparing the maximum wavelength of both Bio-AuNPs, AuNPs reduced by HLRE exhibited a higher wavelength (531 to $544 \mathrm{~nm}$ ) than CLRE (524 to $530 \mathrm{~nm}$ ) (Two-way ANOVA, followed by Bonferroni's test, $p<0.05$ ). Despite a lower absorbance was measured for Bio-AuNPs reduced by HLRE compared to CLRE, but the difference was not statistically significant.

In contrast to that, the maximum wavelength gradually lowered as sodium citrate concentration was increased up to 0.5 and $0.25 \mathrm{mg} / \mathrm{mL}$ for w/o-AuNPs and w-AuNPs, respectively. Further increase in sodium citrate concentration resulted in the shifting to higher wavelength again. The addition of CS into AuNPs also resulted in shifting of the maximum wavelength to a lower value. Both w/o- and w-AuNPs showed a fluctuation of absorbance as sodium citrate concentration was increased. The maximum absorbance was observed at sodium citrate concentration of 1.00 and $0.25 \mathrm{mg} / \mathrm{mL}$ for w/o-AuNPs and w-AuNPs, respectively, indicating high number of AuNPs produced at these concentrations. In general, w-AuNPs had lower absorbance compared to w/oAuNPs except at $0.25 \mathrm{mg} / \mathrm{mL}$ sodium citrate, indicating lower number of AuNPs present after stabilizing with CS, probably due to the CS coating, coated a group of nanoparticles (instead of an individual particle) to form a nanocomposite, consisting of more than one particles (Kiaie et al. 2016). 
The maximum wavelength of Bio-AuNPs was higher than Chem-AuNPs, typically due to larger particle size of Bio-AuNPs. Increase in the maximum wavelength is commonly related to the small particle size (Noruzi 2014; Said et al. 2019). The absorbance of Bio-AuNPs was also slightly higher than Chem-AuNPs, indicating higher number of Bio-AuNPs produced even though the size was larger than Chem-AuNPs. In addition to that, high absorbance number indicates particle size that was formed is larger as the high absorbance enhances the mean free path of electrons in larger nanoparticles (Zuber et al. 2016). In this study, the $\mathrm{pH}$ of both AuNPs was maintained in the range of 6.8 to 7.4 to obtain stable, small and monodisperse particles. At pH 7 (neutral), the red wine color of aqueous solution of AuNPs could be maintained with no sign of aggregation (Wagers et al. 2014).

TABLE 1. Spectroscopic wavelength and absorbance of (a) Chem-AuNPs reduced by different concentrations of sodium citrate and stabilized by CS; (b) Bio-AuNPs prepared using different extraction methods and at various concentrations of CLRE and HLRE, $n=3$

\begin{tabular}{|c|c|c|c|}
\hline (a) & $\begin{array}{l}\text { Sodium citrate concentration } \\
\qquad(\mathrm{mg} / \mathrm{mL})\end{array}$ & Wavelength $(\mathrm{nm}) \pm \mathrm{SD}$ & Absorbance $(\mathrm{A}) \pm \mathrm{SD}$ \\
\hline \multirow[t]{5}{*}{ w/o-AuNPs } & 0.0625 & $564 \pm 31$ & $2.41 \pm 1.35$ \\
\hline & 0.1250 & $536 \pm 6$ & $3.44 \pm 0.25$ \\
\hline & 0.2500 & $534 \pm 8$ & $2.88 \pm 0.91$ \\
\hline & 0.5000 & $510 . \pm 46$ & $2.59 \pm 1.39$ \\
\hline & 1.0000 & $556 \pm 34$ & $4.00 \pm 0.01$ \\
\hline \multirow[t]{5}{*}{ w-AuNPs } & 0.0625 & $500 \pm 139$ & $1.66 \pm 1.30$ \\
\hline & 0.1250 & $501 \pm 56$ & $3.30 \pm 0.96$ \\
\hline & 0.2500 & $466 \pm 66$ & $3.40 \pm 1.05$ \\
\hline & 0.5000 & $505 \pm 28$ & $2.31 \pm 1.85$ \\
\hline & 1.0000 & $530 \pm 60$ & $1.61 \pm 2.07$ \\
\hline
\end{tabular}

\begin{tabular}{|c|c|c|c|}
\hline (b) & LRE concentration $(\mathrm{mg} / \mathrm{mL})$ & Wavelength $(\mathrm{nm}) \pm \mathrm{SD}$ & Absorbance $(\mathrm{A}) \pm \mathrm{SD}$ \\
\hline \multirow[t]{5}{*}{ CLRE } & 0.0625 & $523 \pm 1$ & $3.44 \pm 0.39$ \\
\hline & 0.1250 & $524 \pm 0$ & $3.21 \pm 0.22$ \\
\hline & 0.2500 & $524 \pm 1$ & $3.91 \pm 0.07$ \\
\hline & 0.5000 & $526 \pm 1$ & $3.20 \pm 0.72$ \\
\hline & 1.0000 & $530 \pm 1$ & $3.52 \pm 0.40$ \\
\hline \multirow[t]{5}{*}{ HLRE } & 0.0625 & $531 \pm 1$ & $2.72 \pm 0.36$ \\
\hline & 0.1250 & $532 \pm 4$ & $2.62 \pm 0.40$ \\
\hline & 0.2500 & $537 \pm 3$ & $2.04 \pm 0.22$ \\
\hline & 0.5000 & $539 \pm 3$ & $1.67 \pm 0.78$ \\
\hline & 1.0000 & $544 \pm 1$ & $1.50 \pm 0.33$ \\
\hline
\end{tabular}


Generally, the percent yield for Bio-AuNPs was higher than chem-AuNPs. The yield of Bio-AuNPs from CLRE and HLRE was 83 and $75 \%$, respectively. On the other hand, w-AuNPs produced $65 \%$ of yield while a lower yield was obtained for w/o-AuNPs (62\%). This finding corroborated with a previous report that suggesting the synthesis of AuNPs using plant extracts is a safe method and produces higher yield than chemical method (Ahmad \& Ikram 2015).

\section{PARTICLE SIZE, PDI, AND ZETA POTENTIAL}

Particle size of AuNPs is affected by the type and concentration of reducing and stabilizing agents alongside several other factors including concentration of $\mathrm{HAuCl}_{4}$, reaction temperature, time and $\mathrm{pH}$ (Dubey et al. 2010; Iravani 2011; Philip 2010; Zhao et al. 2012). A decrease in particle size was observed for Bio-AuNPs when CLRE concentration was increased up to $0.25 \mathrm{mg} / \mathrm{mL}$. Further increase in CLRE concentration did not reduce the particle size more, indicating the optimal concentration was achieved at $0.25 \mathrm{mg} / \mathrm{mL}$ for obtaining the smallest particles. In contrast, AuNPs reduced by HLRE showed an increase in particle size by increasing HLRE concentration (Table 2(a)). Although at certain concentrations, CLRE produced smaller particles (from 0.25 to $1 \mathrm{mg} / \mathrm{mL}$ ) compared to HLRE, however, they were not significantly different statistically, indicating the type of extraction had no impact on the particle size at the selected concentrations (Two-way ANOVA, followed up by using Bonferroni's test, $p>0.05$ ). Therefore, the concentration of reducing agent (CLRE and HLRE) had a more important role than the extraction method (to produce different extracts) in influencing the particle size of Bio-AuNPs. The finding is in agreement with another study that using Magnolia kobus and Diopyros kaki extracts as reducing agents (Song et al. 2009).

The size of Chem-AuNPs was also influenced by the concentration of reducing agent. The particle size decreased with the increasing sodium citrate concentration from 0.0625 to 0.25 and $0.125 \mathrm{mg} / \mathrm{mL}$, for w/o-AuNPs and w-AuNPs, respectively (Table 2(b)). Further increase in the concentration of sodium citrate produced larger particles, showing the optimal concentration of reducing agent to obtain the smallest particles could be achieved at 0.25 and $0.125 \mathrm{mg} / \mathrm{mL}$, for w/o-AuNPs $(30.45 \pm 12.21$ $\mathrm{nm})$ and $\mathrm{w}$-AuNPs $(220.43 \pm 43.62 \mathrm{~nm})$, respectively. The opposite relationship was reported previously, but different concentration of $\mathrm{HAuCl}_{4}$ solution was used in the study to synthesize AuNPs (Harimurthi et al. 2013).

Moreover, the size of w/o-AuNPs $(30.45 \pm 12.21$ to $177.73 \pm 13.80 \mathrm{~nm}$ ) was generally smaller than w-AuNPs $(220.43 \pm 43.62$ to $483.79 \pm 12.34 \mathrm{~nm})$. Despite the smaller size of w/o-AuNPs, only the higher sodium citrate concentrations $(0.25,0.5$, and $1 \mathrm{mg} / \mathrm{mL})$ were significantly affected by the addition of CS (two-way ANOVA, followed by Bonferroni's test, $p<0.05$ ), demonstrating the possibility of an interaction between CS and excess reducing agents that might cause adverse effect to the nanoparticles' stability. The larger size of w-AuNPs than w/o-AuNPs was also expected because of CS coating as discussed above. By comparing both Chem- and Bio-AuNPs, larger particle size was observed for Bio-AuNPs than Chem-AuNPs, probably because of CS coating as well. A similar finding was also reported elsewhere, showing an increase in particle size of AuNPs after the addition of CS (Mohan et al. 2019).

TABLE 2. Mean particle size, PDI, and zeta potential of (a) Bio-AuNPs prepared using different extraction method and at various concentrations of CLRE and HLRE; (b) Chem-AuNPs reduced by different concentrations of sodium citrate and stabilized by CS, $n$ $=3$

\begin{tabular}{|c|c|c|c|c|}
\hline (a) & LRE concentration $(\mathrm{mg} / \mathrm{mL})$ & Particle size $(\mathrm{nm}) \pm \mathrm{SD}$ & $\mathrm{PDI} \pm \mathrm{SD}$ & Zeta potential $(\mathrm{mV}) \pm \mathrm{SD}$ \\
\hline \multirow[t]{5}{*}{ CLRE } & 0.0625 & $276.90 \pm 51.62$ & $0.47 \pm 0.04$ & $+32.77 \pm 25.37$ \\
\hline & 0.1250 & $251.90 \pm 102.05$ & $0.43 \pm 0.03$ & $+42.13 \pm 4.37$ \\
\hline & 0.2500 & $208.23 \pm 35.81$ & $0.46 \pm 0.13$ & $+30.33 \pm 21.68$ \\
\hline & 0.5000 & $222.70 \pm 28.42$ & $0.50 \pm 0.10$ & $+42.53 \pm 0.61$ \\
\hline & 1.0000 & $215.20 \pm 27.96$ & $0.58 \pm 0.12$ & $+46.20 \pm 3.40$ \\
\hline \multirow[t]{5}{*}{ HLRE } & 0.0625 & $190.00 \pm 31.66$ & $0.45 \pm 0.02$ & $+45.43 \pm 8.30$ \\
\hline & 0.1250 & $235.87 \pm 42.16$ & $0.51 \pm 0.04$ & $+44.17 \pm 4.38$ \\
\hline & 0.2500 & $246.20 \pm 94.60$ & $0.52 \pm 0.06$ & $+40.30 \pm 3.48$ \\
\hline & 0.5000 & $302.03 \pm 36.97$ & $0.54 \pm 0.07$ & $+48.03 \pm 2.94$ \\
\hline & 1.0000 & $322.07 \pm 27.75$ & $0.68 \pm 0.09$ & $+38.37 \pm 2.27$ \\
\hline
\end{tabular}




\begin{tabular}{|c|c|c|c|c|}
\hline (b) & $\begin{array}{l}\text { Sodium citrate concentration } \\
\qquad(\mathrm{mg} / \mathrm{mL})\end{array}$ & Particle size $(\mathrm{nm}) \pm \mathrm{SD}$ & $\mathrm{PDI} \pm \mathrm{SD}$ & Zeta potential $(\mathrm{mV}) \pm \mathrm{SD}$ \\
\hline \multirow[t]{5}{*}{ w/o-AuNPs } & 0.0625 & $177.73 \pm 13.80$ & $0.315 \pm 0.019$ & $-22.91 \pm 19.35$ \\
\hline & 0.1250 & $48.11 \pm 30.61$ & $0.531 \pm 0.154$ & $-35.2 \pm 1.91$ \\
\hline & 0.2500 & $30.45 \pm 12.21$ & $0.625 \pm 0.028$ & $-38.13 \pm 5.23$ \\
\hline & 0.5000 & $45.45 \pm 16.75$ & $0.448 \pm 0.059$ & $-42.27 \pm 5.03$ \\
\hline & 1.0000 & $71.81 \pm 25.02$ & $0.523 \pm 0.259$ & $-28.02 \pm 11.80$ \\
\hline \multirow[t]{5}{*}{ w-AuNPs } & 0.0625 & $407.20 \pm 186.47$ & $0.429 \pm 0.174$ & $+41.39 \pm 4.36$ \\
\hline & 0.1250 & $220.43 \pm 43.62$ & $0.557 \pm 0.041$ & $+37.22 \pm 1.89$ \\
\hline & 0.2500 & $413.97 \pm 240.01$ & $0.571 \pm 0.091$ & $+39.23 \pm 3.96$ \\
\hline & 0.5000 & $483.79 \pm 12.34$ & $0.414 \pm 0.213$ & $+24.67 \pm 6.24$ \\
\hline & 1.0000 & $381.90 \pm 159.00$ & $0.477 \pm 0.181$ & $+14.78 \pm 4.39$ \\
\hline
\end{tabular}

All AuNPs stabilized by CS had positive surface charge, ranging from $+30.3 \pm 21.6$ to $+46.2 \pm 3.4 \mathrm{mV}$, $+38.4 \pm 2.7$ to $+48 \pm 2.9 \mathrm{mV}$ and $+14.78 \pm 4.36$ to +41.39 $\pm 4.36 \mathrm{mV}$ for Bio-AuNPs reduced by CLRE as well as HLRE and chemically synthesized w-AuNPs, respectively. The positive surface charge was attributed by the presence of CS molecules on the AuNPs surfaces (Esumi et al. 2003). The electrostatic interaction between the positively charged amino groups $\left(\mathrm{NH}^{3+}\right)$ in chitosan and metal salt ions $\left(\mathrm{AuCl}^{4-}\right)$ in solution effectively stabilized the nanoparticles (Bhumkar 2007; Huang \& Yang 2004) and later, facilitated interaction with the negatively charged bacterial cell wall. On the other hand, all w/oAuNPs (Chem-AuNPs) had negative zeta potential values $(-22.91 \pm 19.35$ to $-42.27 \pm 5.03 \mathrm{mV})$. Based on the results, regardless of reducing agent type and concentration, all AuNPS were stable and less prone to aggregation owing to their high surface charge density that more than \pm 30 $\mathrm{mV}$ (Czechowska-Biskup et al. 2015). Generally, AuNPs biosynthesized using plant extracts carry a negative charge on the particle surface (Koperuncholan 2015). The same was also reported for AuNPs synthesized using sodium citrate (Ngo et al. 2015).

PDI of Bio-AuNPs reduced by both extracts was in the range of $0.4-0.7$, indicating the particle size was widely distributed. Meanwhile, Chem-AuNPs had slightly lower PDI values, ranging from 0.3 to 0.6 . Generally, the PDI value of AuNPs increased as more reducing agent was added into the gold ions solution. However, lower values were obtained if more than $0.25 \mathrm{mg} / \mathrm{mL}$ sodium citrate was added, for both w-AuNPs and w/0-AuNPs. Previously, an increase in PDI value was also reported with the increasing sodium citrate concentration (Zabetakis et al. 2012), showing the important of reducing agent in producing monodisperse particles.

\section{ATR-FTIR SPECTROSCOPIC ANALYSIS}

FT-IR analysis of Bio-AuNPs and their single constituents is presented in Figure 1(a). The peak at 3201.18 and $3270.21 \mathrm{~cm}^{-1}$ in the spectrum of CS and L. rhinocerotis extract, respectively, was attributed by the $-\mathrm{OH}$ stretching modes of vibration in alcohols. The peak is then shifted to 3328.16 and $3323.54 \mathrm{~cm}^{-1}$ for Bio-AuNPs synthesized by CLRE and HLRE, respectively. This indicates that $-\mathrm{OH}$ group is mainly responsible for the AuNPs production, reducing $\mathrm{Au}^{3+}$ to $\mathrm{Au}^{0}$ (Mapala \& Pattabi 2017). The spectra of LRE and CS also show IR band characteristics of amide band (1653.27 and $1646.31 \mathrm{~cm}^{-1}$, respectively) and amine band (1071.22 and $1040.83 \mathrm{~cm}^{-1}$, respectively). Additionally, a minor peak at around $2900 \mathrm{~cm}^{-1}$ suggests the presence of carboxylic and phenolic functional groups in LRE (Eskandari-Nojedehi et al. 2017) while in the spectrum of CS, a minor peak corresponds to the presence of carboxylic groups in the polymer structure (Figure 1(a)). Polysaccharides, flavonoids, and terpenoids are the compounds reported to act as reducing and stabilizing agents (Noruzi 2014). The bonds related to amide group $(\mathrm{N}-\mathrm{H})$ represented the presence of proteins on the surface of Bio-AuNPs synthesized from both CLRE and HLRE. The functional groups such as alkaloid or flavones, and the primary amide bonds present in the proteins are the capping ligands of the nanoparticles. The presence of proteins on the surface of nanoparticles can prevent their agglomeration (Chahardoli et al. 2017).

Despite the appearance of peak at $1040 \mathrm{~cm}^{-1}$ (corresponds to amine) for CS spectrum in Figure 1(a), both CS spectra used in the synthesis of Bio- and ChemAuNPs are similar due to the presence of large and intense bands at $3200-3400 \mathrm{~cm}^{-1}$, relating to the hydrogenbonded $\mathrm{O}-\mathrm{H}$ stretches overlapped with a number of $\mathrm{N}-\mathrm{H}$ stretching bands. Moreover, the characteristic peaks at 
1640 and $1340 \mathrm{~cm}^{-1}$ are corresponding to $\mathrm{C}=\mathrm{O}$ stretching (amide I) and $\mathrm{C}-\mathrm{N}$ stretching (amide III) modes of the residual $\mathrm{N}$-acetyl groups, respectively (Wang et al. 2016). Furthermore, the appearance of peak will only provide qualitative estimation of the amount of a moiety (Blando et al. 2001), explaining the insignificant peak of amine at around $1040 \mathrm{~cm}^{-1}$ as shown in Figure 1(b). Based on Figure 1(b), sodium citrate showed characteristics peak at 3340.81 (-OH stretching), 2170.99 and 2108.76 (C $\equiv \mathrm{C}$ stretching) and $1636.96 \mathrm{~cm}^{-1}$ (- $\mathrm{COO}^{-}$stretching). Sodium citrate possesses functional groups of amide and hydroxyl
(Mohan et al. 2013) which also found in Chem-AuNPs spectra, indicating the formation of Chem-AuNPs by sodium citrate. The citrate ions act as reducing agents which react with $\mathrm{Au}^{3+}$ to form $\mathrm{Au}^{0}$ (gold atom). The citrate ions also act as stabilizing agents, wrapping around the cluster of atoms which constitute the nanoparticles. This negative charge introduced on the surface of nanoparticles by citrate ions creates an electrostatic repulsion around the nanoparticle which repels from each other. Hence, it prevents aggregation and stabilizes the nanoparticles (Nayfeh 2018).

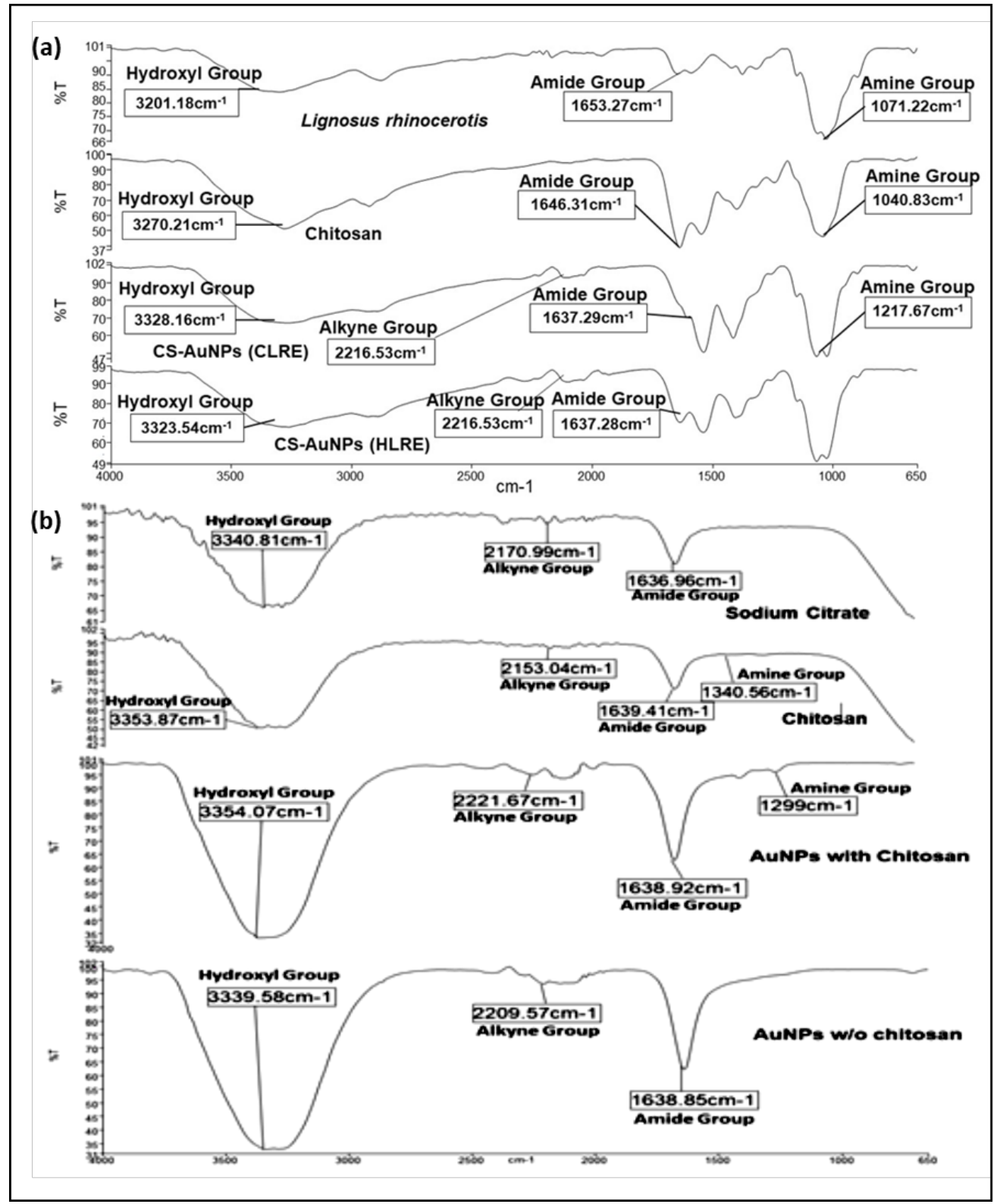

FIGURE 1. FTIR spectra of (a) Bio-AuNPs synthesized and their single constituents (CLRE, HLRE and CS); (b) Chem-AuNPs and their single constituents (sodium citrate and CS) 


\section{MORPHOLOGY OF THE CS-AUNPS}

Morphology of Bio-AuNPs was viewed under a scanning electron microscope (SEM) and transmission electron microscope (TEM) as shown in Figure 2(a) and 2(b) and morphology of Chem-AuNPs was viewed under TEM only. The particle size was also determined by using Image $\mathbf{J}$ software based on the SEM micrographs. In this analysis, the concentrations that produced small particles were selected from both Bio-AuNPs ( 1 and $0.25 \mathrm{mg} / \mathrm{mL}$ for CLRE, while 0.125 and $0.06 \mathrm{mg} / \mathrm{mL}$ for CLRE) and Chem-AuNPs $(0.125$ and $0.25 \mathrm{mg} / \mathrm{mL}$ for $\mathrm{w}$-AuNPs and w/o-AuNPs, respectively). Based on SEM analysis, BioAuNPs were mostly irregular and spherical in shape with the particle size ranged from 110 to $140 \mathrm{~nm}$ and 50-150 $\mathrm{nm}$ for CLRE and HLRE, respectively. AuNPs reduced by $M$. piperita were also spherical in shape with the size about $150 \mathrm{~nm}$ (Mubarak Ali et al. 2011) while by using Papaver somniferum extract, AuNPs with triangular structure were produced and the average size was about $77 \mathrm{~nm}$ (Wali et al. 2017). For TEM analysis, spherical particles were mostly observed with some other shapes including triangular, pentagonal and hexagon in Bio-
AuNPs sample. Similar to Bio-AuNPs, in Chem-AuNPs sample, spherical particles are the major shape along with pentagonal, oval and hexagon. Previous study stated that the different shape of nanoparticles has been reported to kill bacteria differently and therefore, exhibit different antibacterial effect (Penders et al. 2017). Through TEM analysis, average size of Bio-AuNPs synthesized from $0.25 \mathrm{mg} / \mathrm{mL}$ CLRE was $14.6 \mathrm{~nm}$ while for CS-AuNPs synthesized from $1 \mathrm{mg} / \mathrm{mL}$ CLRE was $17.69 \mathrm{~nm}$. Average size of CS-AuNPs synthesized from $0.12 \mathrm{mg} / \mathrm{mL}$ HLRE was $20.6 \mathrm{~nm}$ while for CS-AuNPs synthesized from 0.06 $\mathrm{mg} / \mathrm{mL}$ CLRE was $21.3 \mathrm{~nm}$. Chem-AuNPs synthesized with chitosan produces larger size (average size $=8.66$ $\mathrm{nm}$ ) as compared to the one synthesized without chitosan (average size $=4.07 \mathrm{~nm}$ ). A study reported that AuNPs synthesized from chitosan as reducing and stabilizing agent, through TEM analysis, AuNPs formed were spherical in shape with the average size of 8-10 $\mathrm{nm}$ (Lanh Le et al. 2014). Morphological analysis proven that both Bioand Chem-AuNPs had similar shape but smaller sizes of Chem-AuNPs were observed which in agreement with the results obtained from the laser light scattering technique.

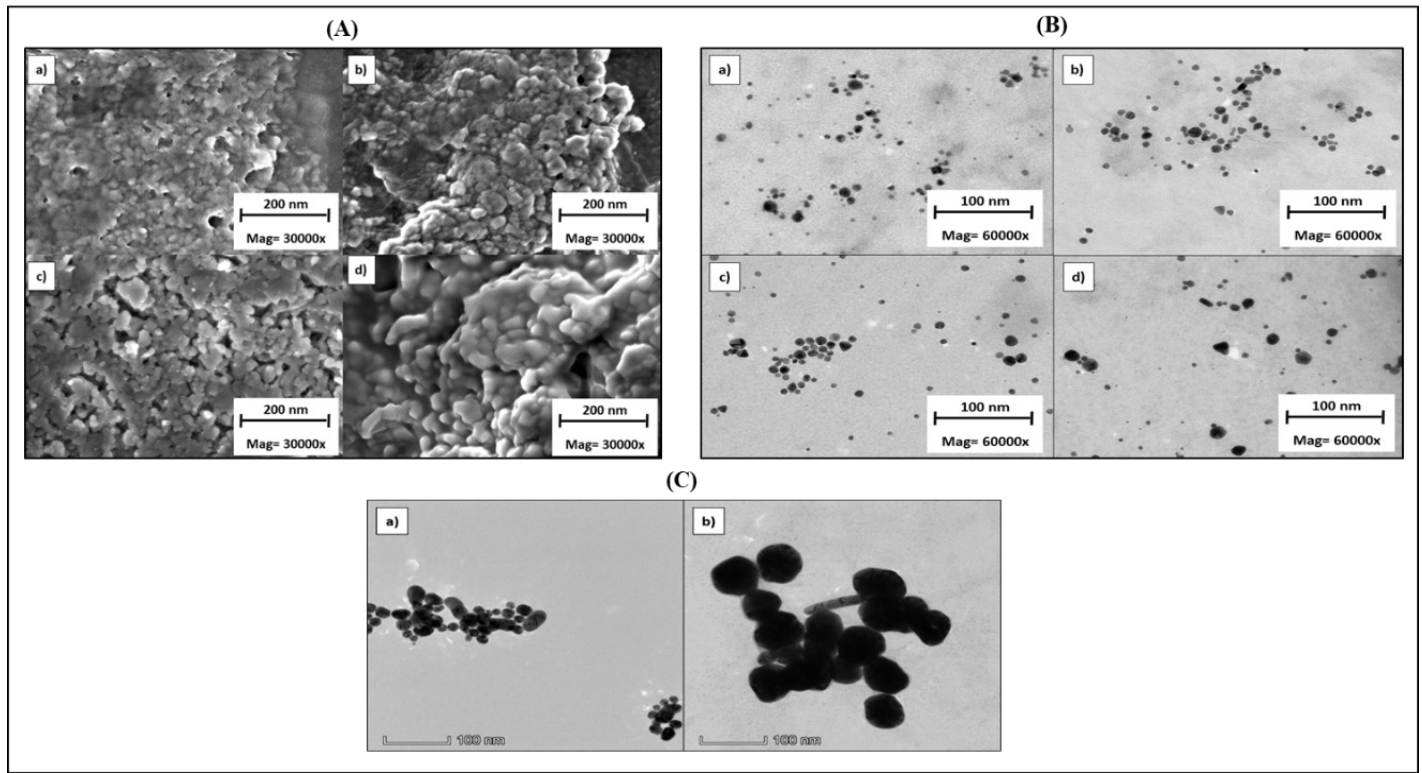

FIGURE 2. (A) SEM and (B) TEM micrographs of Bio-AuNPs reduced by LRE (a) 0.25 $\mathrm{mg} / \mathrm{mL}$ CLRE, (b) $1 \mathrm{mg} / \mathrm{mL}$ CLRE, (c) $0.0625 \mathrm{mg} / \mathrm{mL}$ HLRE and (d) $0.125 \mathrm{mg} / \mathrm{mL}$ HLRE. (C) TEM micrographs of (a) w/o-AuNPs reduced by $0.25 \mathrm{mg} / \mathrm{mL}$ sodium citrate and (b) $\mathrm{w}$-AuNPs reduced by $0.125 \mathrm{mg} / \mathrm{mL}$ sodium citrate

\section{ANTIBACTERIAL ACTIVITY OF THE BIO-AUNPS AND CHEM- AUNPS}

Antibacterial test was carried out using $\mathrm{MH}$ agar well diffusion method as reported previously (Rajan et al. 2017) on selected gram-positive (S. aureus and Bacillus sp.) and gram-negative bacteria ( $P$. aeruginosa and E. coli). Based on the results in Table 3, regardless of extract type, Bio-AuNPs exhibited antibacterial activity against all the selected bacteria except for Bacillus sp. Despite particle size of Bio-AuNPs was relatively large, but they still 
inhibited the growth of bacteria effectively, demonstrating the effect might not be entirely depending on the particle size, at least for Bio-AuNPs. The antibacterial activity might be also attributed by CS because amino groups in its structure interact with the bacteria via ionic interaction, damaging the bacterial membrane (Kang et al. 2016; Ye et al. 2005). Among other Bio-AuNPs, the ones reduced by $0.25 \mathrm{mg} / \mathrm{mL}$ CLRE as well as 0.0625 and $0.125 \mathrm{mg} /$ $\mathrm{mL}$ had shown higher antibacterial activity. This could be attributed by their smaller particle size which provided larger surface area for effective contact with the bacterial surface and thus, enhancing antimicrobial efficiency (Ye et al. 2005). This finding therefore suggested that by influencing the particle size, LRE concentration was indirectly affecting the antibacterial activity of Bio-AuNPs. Additionally, the antibacterial activity was not affected by extraction method except for Bio-AuNPs reduced by the lowest concentration of LRE against $S$. aureus (twoway ANOVA, followed by Bonferroni's test, $p<0.05)$ as HLRE exhibited better effect than CLRE, probably because of smaller particle size of HLRE compared to CLRE.

TABLE 3. Zone of inhibition (mm) of $S$. aureus, Bacillus sp., P. aeruginosa, and E. coli for Bio-AuNPs prepared using different extraction methods and at various concentrations of CLRE and HLRE, $n=3$

\begin{tabular}{|c|c|c|c|c|c|}
\hline & \multirow{2}{*}{$\begin{array}{l}\text { LRE concentration } \\
(\mathrm{mg} / \mathrm{mL})\end{array}$} & \multicolumn{4}{|c|}{ Zone of inhibition (mm) } \\
\hline & & S. aureus & Bacillus sp. & P. aeruginosa & E. coli \\
\hline \multirow[t]{5}{*}{ CLRE } & $* 0.0625$ & $* 3 \pm 6$ & - & $7 \pm 6$ & $4 \pm 7$ \\
\hline & 0.1250 & $11 \pm 1$ & - & $8 \pm 7$ & $4 \pm 7$ \\
\hline & 0.2500 & $11 \pm 1$ & - & $12 \pm 1$ & $11 \pm 1$ \\
\hline & 0.5000 & $9 \pm 1$ & - & $7 \pm 6$ & $7 \pm 7$ \\
\hline & 1.0000 & $9 \pm 1$ & - & $10 \pm 1$ & $11 \pm 0$ \\
\hline $\begin{array}{c}+ \text { control } \\
\text { (Gentamicin })\end{array}$ & & $32 \pm 2$ & $33 \pm 1$ & $34 \pm 0$ & $29 \pm 2$ \\
\hline $\begin{array}{c}\text { - control (distilled } \\
\text { water) }\end{array}$ & & - & - & - & - \\
\hline \multirow[t]{5}{*}{ HLRE } & $* 0.0625$ & $* 11 \pm 1$ & $3 \pm 6$ & $10 \pm 0$ & $4 \pm 7$ \\
\hline & 0.1250 & $11 \pm 1$ & $4 \pm 7$ & $11 \pm 1$ & $4 \pm 7$ \\
\hline & 0.2500 & $11 \pm 0$ & - & $6 \pm 6$ & $7 \pm 6$ \\
\hline & 0.5000 & $11 \pm 0$ & - & $9 \pm 0$ & - \\
\hline & 1.0000 & $10 \pm 0$ & - & $9 \pm 1$ & $11 \pm 0$ \\
\hline $\begin{array}{c}+ \text { control } \\
\text { (Gentamicin })\end{array}$ & & $31 \pm 2$ & $32 \pm 1$ & $36 \pm 0$ & $30 \pm 0$ \\
\hline $\begin{array}{c}\text { - control (distilled } \\
\text { water) }\end{array}$ & & - & - & - & - \\
\hline
\end{tabular}

-Zone of inhibition of bacteria unsubstantiated. *Significantly different between CLRE and HLRE $(\mathrm{p}<0.05)$. All tested samples were significantly different from the positive control $(\mathrm{p}<0.05)$

All selected bacteria were affected by the presence of Chem-AuNPs as shown in Table 4(a). However, the antibacterial activity could only be seen for w/o-AuNPs reduced by lower concentrations of sodium citrate $(0.0625$ to $0.125 \mathrm{mg} / \mathrm{mL})$. Above $0.125 \mathrm{mg} / \mathrm{mL}$ sodium citrate, antibacterial activity was not detected except for w-AuNPs against $S$. aureus, showing the possibility of synergistic effect of combining AuNPs and CS. The antibacterial activity of Chem-AuNPs was apparently affected by the concentration of sodium citrate, as the antibacterial activity reduced when the concentration was increased. Higher concentration of citrate was reported to produce AuNPs with reduced inhibitory effect compared to lower concentration (Zhou et al. 2012). This could be due to the aggregation of AuNPs as metal nanoparticles tend to aggregate, resulting reduced interaction between AuNPs and bacterial membrane. This also resulted in fewer non-aggregated nanoparticles available to penetrate 
the bacteria. Hence, bacterial growth was only slightly inhibited.

It can be observed that generally, w/o-AuNPs had a better antibacterial effect than w-AuNPs for all bacteria strains. However, the effect was only significantly different for gram-negative bacteria (two-way ANOVA, followed by Bonferroni's test, $p<0.05)$. Based on the results, w/o-AuNPs showed a better antibacterial activity than w-AuNPs, owing to the smaller size of w/o-AuNPs (177.73 \pm 13.80 and $48.11 \pm 30.61$ for 0.0625 and $0.125 \mathrm{mg} / \mathrm{mL}$, respectively). Therefore, in case of Chem-AuNPs, particle size is thought to play a more important role in inhibiting bacteria growth, compared to other factors such as positive surface charge of w/o-AuNPs. Despite that, it could also be seen that the smaller size of w/o-AuNPs reduced by $0.125 \mathrm{mg} / \mathrm{mL}$ sodium citrate $(48 \mathrm{~nm})$ did not show superior inhibitory effect than the $0.0625 \mathrm{mg} / \mathrm{mL}$ sodium citrate $(178 \mathrm{~nm})$, probably the effect had a certain acceptable particle size range, not too small or big.

Furthermore, the antibacterial activity of $1 \% \mathrm{w} / \mathrm{v} \mathrm{CS}$ and LRE (CLRE and HLRE) were evaluated and the results are shown in Table 4(b). CS exhibited antibacterial activity against all bacteria tested except for Bacillus sp. Both CLRE and HLRE did not show any antibacterial activity although a study elsewhere reported that LRE had the highest antibacterial activity at $30 \mathrm{mg} / \mathrm{mL}$, probably due to different extraction method used (Mohanarji et al. 2012). Katas et al. (2018) prepared AuNPs using LRE and different CS concentrations $(0.2,0.4,0.6,0.8,1.0$, and $1.2 \%$ w/v) to produce CS-stabilized AuNPs (CS-AuNPs). Both $S$. aureus and $P$. aeruginosa were affected by CS-AuNPs and the effect increased by increasing CS concentration. The highest activity was recorded with AuNPs stabilized using $1 \% \mathrm{w} / \mathrm{v} \mathrm{CS}$ and therefore, the concentration was used in this study.

TABLE 4. Zone of inhibition (mm) of S. aureus, Bacillus sp., P. aeruginosa, and E. coli for (a) Chem-AuNPs prepared using different concentrations of sodium citrate and stabilized by CS; (b) CS and LRE, $\mathrm{n}=3$

\begin{tabular}{|c|c|c|c|c|c|}
\hline \multirow[t]{2}{*}{ (a) } & \multirow{2}{*}{$\begin{array}{l}\text { Sodium citrate } \\
\text { concentration } \\
(\mathrm{mg} / \mathrm{mL})\end{array}$} & \multicolumn{4}{|c|}{ Zone of inhibition (mm) } \\
\hline & & S. aureus & Bacillus sp. & P. aeruginosa & E. coli \\
\hline \multirow[t]{5}{*}{ w/o-AuNPs } & 0.0625 & $22 \pm 2$ & $14 \pm 1$ & $* 19 \pm 1$ & $* 20 \pm 1$ \\
\hline & 0.1250 & $19 \pm 2$ & $8 \pm 7$ & $* 12 \pm 1$ & $* 15 \pm 1$ \\
\hline & 0.2500 & - & - & - & - \\
\hline & 0.5000 & - & - & - & - \\
\hline & 1.0000 & - & - & - & - \\
\hline \multirow[t]{5}{*}{ w-AuNPs } & 0.0625 & $15 \pm 0$ & $13 \pm 1$ & $* 10 \pm 0$ & $* 11 \pm 0$ \\
\hline & 0.1250 & $11 \pm 10$ & $13 \pm 0$ & $* 18 \pm 0$ & $* 12 \pm 0$ \\
\hline & 0.2500 & $4 \pm 8$ & - & - & - \\
\hline & 0.5000 & - & - & - & - \\
\hline & 1.0000 & $3 \pm 6$ & - & - & - \\
\hline $\begin{array}{c}+ \text { control } \\
\text { (Gentamicin) }\end{array}$ & & $30 \pm 1$ & $31 \pm 1$ & $31 \pm 4$ & $30 \pm 2$ \\
\hline $\begin{array}{c}\text { - control (distilled } \\
\text { water) }\end{array}$ & & - & - & - & - \\
\hline
\end{tabular}

(b)

Zone of inhibition (mm)

\begin{tabular}{ccccc} 
& S. aureus & Bacillus sp. & P. aeruginosa & E. coli \\
\hline $1 \%$ w/v chitosan & $9 \pm 0$ & - & $8 \pm 0$ & $9 \pm 0$ \\
\hline CLRE & - & - & - & - \\
\hline HLRE & - & - & - & -
\end{tabular}

- Zone of inhibition of bacteria unsubstantiated. *Significantly different between w/o-AuNPs and w-AuNPs $(\mathrm{p}<0.05)$. All tested samples were significantly different from the positive control $(\mathrm{p}<0.05)$ 
MIC AND MBC

For determination of MIC and MBC, Bio-AuNPs with the highest activity for each extract (CLRE and HLRE) were selected. Therefore, MIC was determined for BioAuNPs reduced by $0.25 \mathrm{mg} / \mathrm{mL}$ CLRE and $0.125 \mathrm{mg} / \mathrm{mL}$ HLRE. The MIC value for Bio-AuNPs was determined by spectrophotometric method using a microplate reader. In this method, MIC was defined as the concentration at which there was a sharp decline in the absorbance value (Devienne \& Raddi 2002). The optical density of bacteria was measured at a wavelength of $600 \mathrm{~nm}$ to minimize the background absorbance as bacteriological media (yellow) has a low absorbance at this wavelength (McBirney et al. 2016). Generally, Bio-AuNPs synthesized by HLRE exhibited a better antibacterial activity compared to CLRE as shown by their MIC values in Figure 3. Although both Bio-AuNPs had the same MIC against Staphylococcus aureus $(100 \mu \mathrm{g} / \mathrm{mL})$, however, in case of Escherichia coli, MIC of Bio-AuNPs reduced by CLRE was higher than HLRE as a sharp decline was observed at 200 $\mu \mathrm{g} / \mathrm{mL}$ and $50 \mu \mathrm{g} / \mathrm{mL}$ for CLRE and HLRE, respectively. Moreover, MIC for Bio-AuNPs synthesized from CLRE was 2 -fold higher $(200 \mu \mathrm{g} / \mathrm{mL})$ than HLRE $(100 \mu \mathrm{g} / \mathrm{mL})$ against $P$. aeruginos $a$. AuNPs reduced by other extracts, Ocimum tenuiflorum, Azadirachta indica, and Mentha spicata and Citrus sinensis plants were also reported to inhibit gram positive and negative bacteria at the range of $512-600 \mu \mathrm{g} / \mathrm{mL}$ (Rao et al. 2017). AuNPs inhibit the bacteria by rupturing the cell wall and disturbing the metabolism of bacteria via chemical reactions. Smaller size of spherical AuNPs provides larger surface area that may significantly contribute to their antibacterial activity (Khan et al. 2016). MBC is defined as the minimum concentration of an antimicrobial drug that is bactericidal. MBC is determined by sub-culturing broth dilutions that considered as point of MIC and the broth dilutions are streaked onto agar prior to incubation for $24 \mathrm{~h}$ (Sykes \& Rankin 2014). Both Bio-AuNPs had bacteriostatic effect as the growth of bacteria was seen on the MH agar after $24 \mathrm{~h}$, indicating their ability to inhibit rather than kill the bacteria (Figure 4).
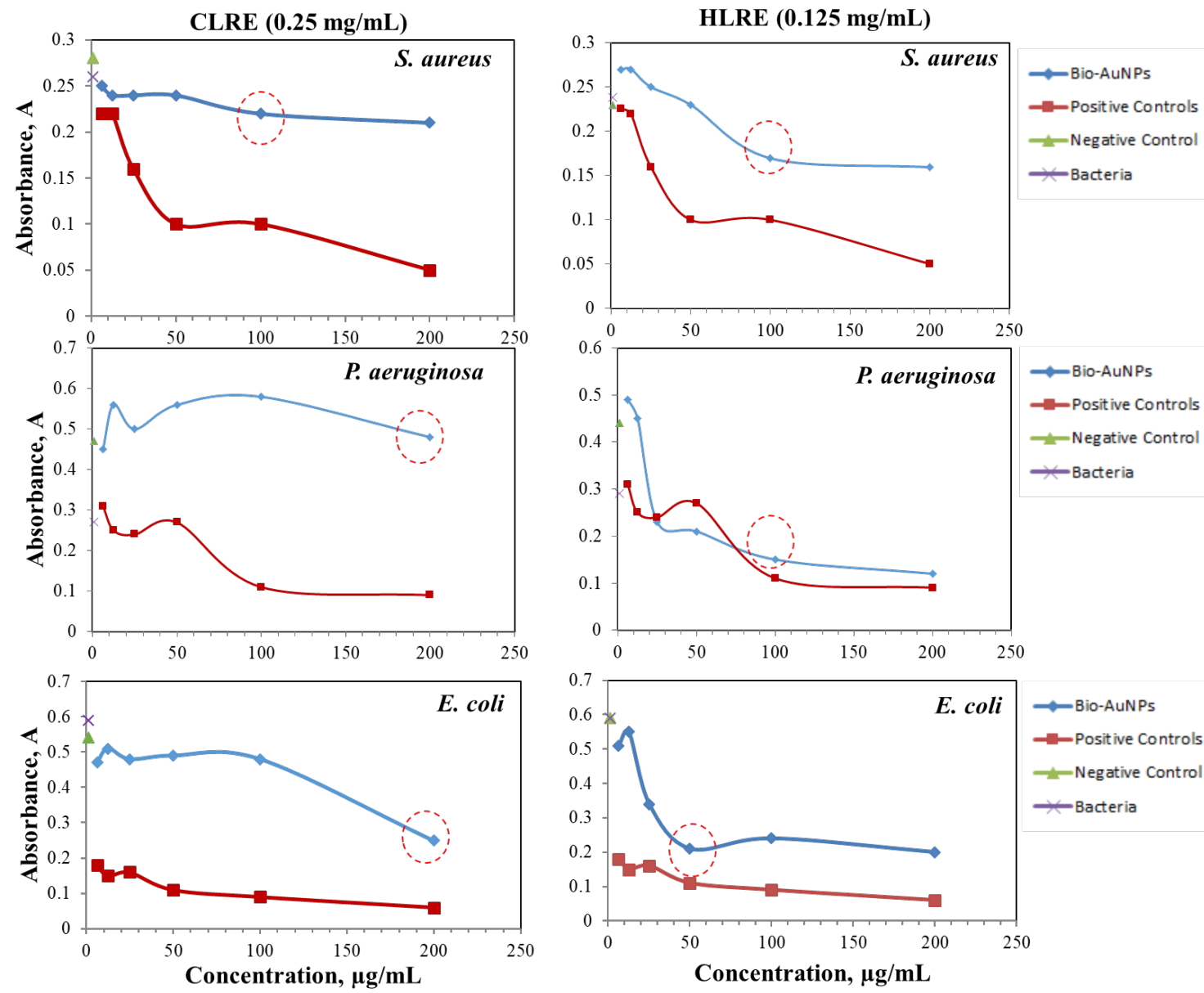

FIGURE 3. MIC of Bio-AuNPs against S. aureus, P. aeruginosa and E. coli 


\section{CELL VIABILITY TEST}

Cell viability is a determination of either living or dead cells, based on the total sample cells. This test was carried out to evaluate the cytotoxicity of AuNPs synthesized by either chemical or biological method. In this study, only optimized AuNPs with high antibacterial activity for both methods were selected. Both Chem-AuNPs showed a decreasing cell viability, as the concentration of nanoparticles was increased (Table 4(a)). Similar findings were reported by others and citrate was reported to cause adverse effect on the cells (Pernodet et al. 2006; Vijayakumar et al. 2012). Citrate-based nanoparticles will cause the proliferation of dermal fibroblasts to be disrupted and actin filaments to develop abnormally, leading to decrease in motility (Vijayakumar et al. 2012). These results indicate that internal cell function was impaired. Based on the results, it could also be seen that w-AuNPs had a better cell viability than w/o-AuNPs as CS could improve the biocompatibility of metallic nanoparticles (Cinteza et al. 2018).

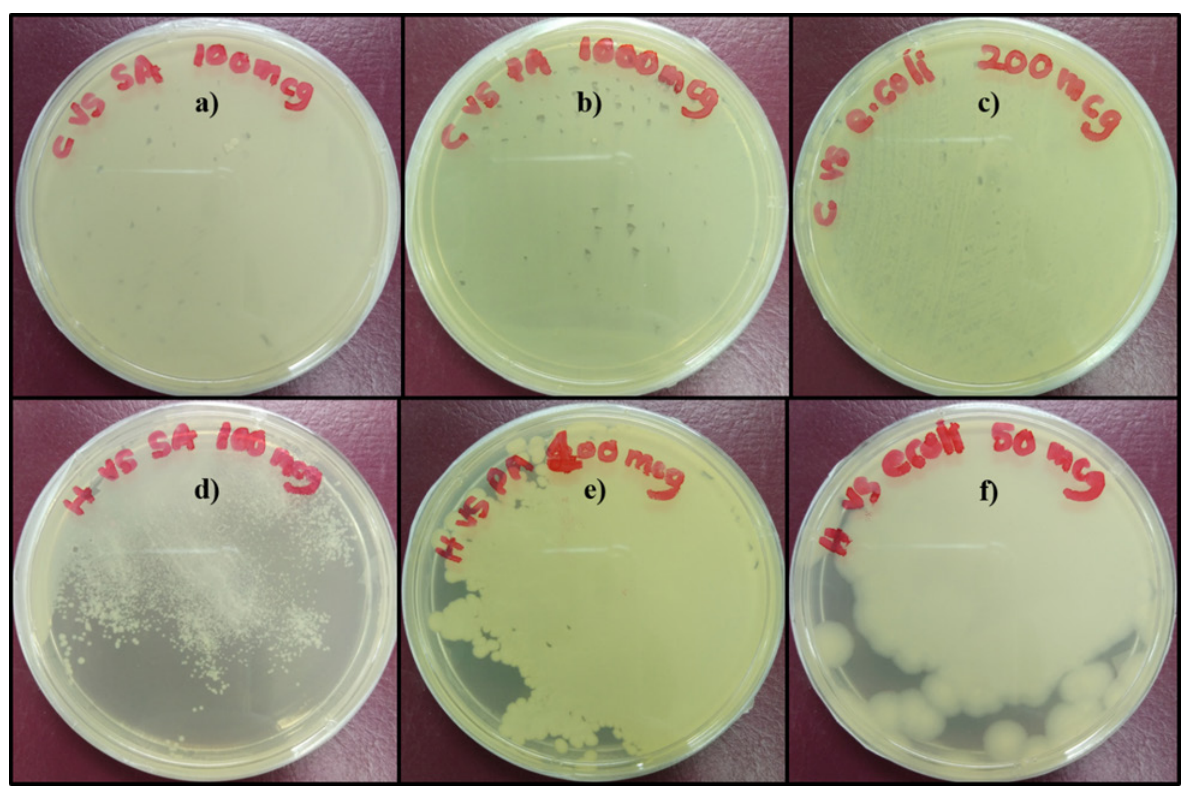

FIGURE 4. MBC of Bio-AuNPs reduced by CLRE against (a) S. aureus, (b) P. aeruginosa and (c) E. coli as well as Bio-AuNPs reduced by HLRE against (d) $S$. aureus, (e) P. aeruginosa and (f) E. coli

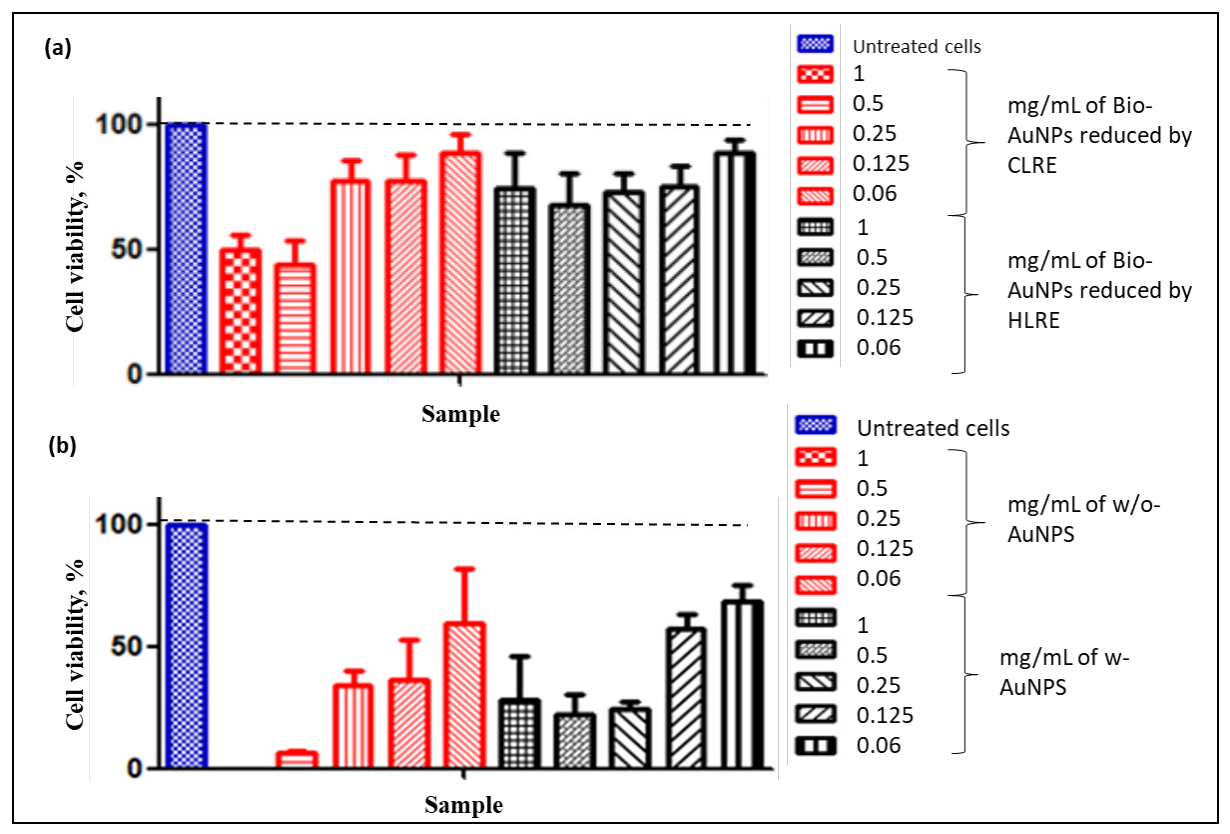

FIGURE 5. Cell viability (\%) of HDF for (a) Bio-AuNPs and (b) Chem-AuNPs at various concentrations for $24 \mathrm{~h}$ exposure, $\mathrm{n}=3$ 
On the other hand, Bio-AuNPs reduced by both CLRE and HLRE showed concentration-dependent cytotoxicity, by which decreasing cell viability was observed as the concentration of AuNPs was increased (Table 4(b)). Moreover, the cytotoxicity effect was not affected by the type of extraction method (two-way ANOVA, followed by Bonferroni's test, $p>0.05$ ). In comparison to Chem-AuNPs, Bio-AuNPs were proven to be less toxic. Similar findings were also reported using another mushroom extract (Ganoderma spp.) that showed lower cytotoxicity of biosynthesized AuNPs than the chemically synthesized ones (Gurunathan et al. 2014).

\section{CONCLUSION}

CS-stabilized AuNPs formed using either chemical or biological method exhibited larger particle size compared to non-stabilized AuNPs (w/o-AuNPs). Both synthesis methods produced AuNPs with antibacterial activity although Bio-AuNPs had larger particle size than Chem-AuNPs, probably due to the presence of CS and L. rhinocerotis extracts, capping the surface of AuNPs. Moreover, Bio-AuNPs were relatively less cytotoxic than Chem-AuNPs. Thus, it proved that Bio-AuNPs were safer than Chem-AuNPs as an antibacterial agent.

\section{ACKNOWLEDGEMENTS}

This work was funded by the Arus Perdana grant provided by Universiti Kebangsaan Malaysia (AP-2017$003)$.

\section{REFERENCES}

Ahmed, S. \& Ikram, S. 2015. Synthesis of gold nanoparticles using plant extract: An overview. Nano Research and Application 1(1): 1-6.

Ahmed, D.S., Mohammed, T.H., Risan, M.H., Najim, L.H., Mohammed, S.S., Yusop, R.M. \& Yousif, E. 2019. Green synthesis of silver nanoparticles by plants extract. International Journal of Chemical and Process Engineering Research 6(1): 1-6.

Alaqad, K. \& Saleh, T.A. 2016. Gold and silver nanoparticles: Synthesis methods, characterization routes and applications towards drugs. Journal of Environmental \& Analytical Toxicology 6: 4 .

Asharavani, P.V., Lianwu, Y. \& Valiyaveettil, S. 2010. Comparison of the toxicity of silver, gold and platinum nanoparticles in developing Zebrafish embryos. Nanotoxicology 5(1): 43-54.

Bhumkar, D.R., Joshi, H.M., Sastry, M. \& Pokharkar, V.B. 2007. Chitosan reduced gold nanoparticles as novel carriers for transmucosal delivery of insulin. Pharmaceutical Research 24(8): 1415-1426.

Blando, J.D., Porcja, R.J. \& Turpin, B.J. 2001. Issues in the quantitation of functional groups by FTIR spectroscopic analysis of impactor-collected aerosol samples. Aerosol Science and Technology 35(5): 899-908.

Bonardd, S., Schmidt, M., Saavedra-Torres, M., Leiva, A., Radic, D. \& Saldías, C. 2016. Thermal and morphological behavior of chitosan/Peo blends containing gold nanoparticles:
Experimental and theoretical studies. Carbohydrate Polymers 144: 315-329.

Cinteza, L., Scomoroscenco, C., Voicu, S., Nistor, C., Nitu, S., Trica, B., Jecu, M.L. \& Petcu, C. 2018. Chitosan-stabilized Ag nanoparticles with superior biocompatibility and their synergistic antibacterial effect in mixtures with essential oils. Nanomaterials 8(10): 826.

Chahardoli, A., Karimi, N., Sadeghi, F. \& Fattahi, A. 2017. Green approach for synthesis of gold nanoparticles from Nigella arvensis leaf extract and evaluation of their antibacterial, antioxidant, cytotoxicity and catalytic activities. Artificial Cells, Nanomedicine, and Biotechnology 46(3): 579-588.

Chokriwal, A., Sharma, M.M. \& Singh, A. 2014. Biological synthesis of nanoparticles using bacteria and their applications. American Journal of Pharmtech Research 4(6): 38-61.

Czechowska-Biskup, R., Rokita, B., Ulański, P., Rosiak, J.M., Chitin, A.O. \& Derivatives, I. 2015. Preparation of gold nanoparticles stabilized by chitosan using irradiation and sonication methods. Progress on Chemistry and Application of Chitin and its Derivatives 20: 18-33.

Control for Disease and Prevention. 2019. Antibiotic Resistance Threats in the United States, 2019. Centres for Disease Control and Prevention, US Department of Health.

Devienne, K.F. \& Raddi, M.S.G. 2002. Screening for antimicrobial activity of natural products using a microplate photometer. Brazilian Journal of Microbiology 33(2): 166-168.

Dubey, S.P., Lahtinen, M. \& Sillanpää, M. 2010. Tansy fruit mediated greener synthesis of silver and gold nanoparticles. Process Biochemistry 45(7): 1065-1071.

Eskandari-Nojedehi, M., Jafarizadeh-Malmiri, H. \& RahbarShahrouzi, J. 2017. Hydrothermal green synthesis of gold nanoparticles using mushroom (Agaricus bisporus) extract: Physico-chemical characteristics and antifungal activity studies. Green Processing and Synthesis 7(1): 38-47.

Esumi, K., Houdatsu, H. \& Yoshimura, T.J.L. 2004. Antioxidant action by Gold-PAMAM dendrimer nanocomposites. Langmuir 20(7): 2536-2538.

Gurunathan, S., Han, J., Park, J.H. \& Kim, J.H. 2014. A green chemistry approach for synthesizing biocompatible gold nanoparticles. Nanoscale Research Letters 9(1): 248.

Harimurti, S., Rohiman, A., Sulthoni, M.A. \& Idris, I. 2013. The effect of trisodium citrate concentration on the size of gold nanoparticles. Proceeding in International Conference on Electronics Technology and Industrial Development. pp. 282-284.

Huang, H. \& Yang, X. 2004. Synthesis of chitosan-stabilized gold nanoparticles in the absence or presence of tripolyphosphate. Biomacromolecules 5(6): 2340-2346.

Hussain, M.A., Shah, A., Jantan, I., Shah, M.R., Tahir, M.N., Ahmad, R. \& Bukhari, S.N.A. 2015. Hydroxypropylcellulose as a novel green reservoir for the synthesis, stabilization, and storage of silver nanoparticles. International Journal of Nanomedicine 10: 2079-2088.

Iravani, S. 2011. Green synthesis of metal nanoparticles using plants. Green Chemistry 13(10): 2638-2650.

Ishak, N.I.A.M.S., Kamarudin, K. \& Timmiati, S.N. 2019. Green synthesis of metal and metal oxide nanoparticles via plant extracts: An overview. Materials Express Research 6: 112004.

Kang, Y., Jung, J.Y., Cho, D., Kwon, O., Cheon, J. \& Park, W. 2016. Antimicrobial silver chloride nanoparticles stabilized 
with chitosan oligomer for the healing of burns. Materials 9(4): 215.

Katas, H., Moden, N.Z., Lim, C.S., Celesistinus, T., Yee, C.J., Ganasan, P. \& Abdalla, S.S.I. 2018. Biosynthesis and potential applications of silver and gold nanoparticles and their chitosan-based nanocomposites in nanomedicine. Journal of Nanotechnology 2018: Paper ID. 4290705.

Katas, H., Lim, C.S., Nor Azlan, A.Y.H., Buang, F. \& Busra, M.F.M. 2019. Antibacterial activity of biosynthesized gold nanoparticles using biomolecules from Lignosus rhinocerotis and chitosan. Saudi Pharmaceutical Journal 27(2): 283-292.

Kaviya, S. 2017. Rapid naked eye detection of arginine by pomegranate peel extract stabilized gold nanoparticles. Journal of King Saud University-Science 31(4): 864-868

Khan, A.U., Yuan, Q., Wei, Y., Khan, G.M., Khan, Z.U.H., Khan, S. \& Khan, F.U. 2016. Photocatalytic and antibacterial response of biosynthesized gold nanoparticles. Journal of Photochemistry and Photobiology B: Biology 162: 273-277.

Kiaie, N., Aghdam, R.M., Tafti, S.H. \& Emami, S.H. 2016. Statistical optimization of chitosan nanoparticles as protein vehicles, using response surface methodology. Journal of Applied Biomaterials and Functional Materials 14(4): 413-422.

Koperuncholan, M. 2015. Bioreduction of chloroauric acid (Haucl4) for the synthesis of Gold Nanoparticles (Gnps): A special empathies of pharmacological activity. International Journal of Phytopharmacy 5(4): 72-80.

Lanh Le, T., Khieu Dinh, Q., Hoa Tran, T., Phong Nguyen, H., Le Hien Hoang, T. \& Hien Nguyen, Q. 2014. Synthesis of water soluble chitosan stabilized gold nanoparticles and determination of uric acid. Advances in Natural Sciences: Nanoscience and Nanotechnology 5(2): 025014.

Mapala, K. \& Pattabi, M. 2017. Mimosa pudica flower extract mediated green synthesis of gold nanoparticles. Nano World Journal 3(2): 44-50.

McBirney, S.E., Trinh, K., Wong-Beringer, A. \& Armani, A.M. 2016. Wavelength-normalized spectroscopic analysis of Staphylococcus aureus and Pseudomonas aeruginosa growth rates. Biomedical Optics Express 7(10): 4034-4042.

Mohan, C.O., Gunasekaran, S. \& Ravishankar, C.N. 2019. Chitosan-capped gold nanoparticles for indicating temperature abuse in frozen stored products. npj Science Food 3(2): 1-6.

Mohan, J.C., Praveen, G., Chennazhi, K., Jayakumar, R. \& Nair, S.V. 2013. Functionalised gold nanoparticles for selective induction of in vitro apoptosis among human cancer cell lines. Journal of Experimental Nanoscience 8(1): 32-45.

Mubarak Ali, D., Thajuddin, N., Jeganathan, K. \& Gunasekaran, M. 2011. Plant extract mediated synthesis of silver and gold nanoparticles and its antibacterial activity against clinically isolated pathogens. Colloids and Surfaces. B, Biointerfaces 85(2): 360-365.

Nayak, M.P. 2014. Green synthesis of gold nanoparticles using Solanus lycopersicum (TOMATO) aqueous extract. World Journal of Nano Science and Technology 3(2): 74-80.

Nayfeh, M.H. 2018. Micro and Nano Technologies Fundamentals and Applications of Nano Silicon in Plasmonics and Fullerines: Current and Future Trend. 1st edition. Amsterdam: Elsevier.

Nazirov, A., Pestov, A., Privar, Y., Ustinov, A., Modin, E. \& Bratskaya, S. 2016. One-pot green synthesis of luminescent gold nanoparticles using imidazole derivative of chitosan Carbohydrate Polymers 151: 649-655.

Ngo, V.K.T., Nguyen, H.P.U., Huynh, T.P., Tran, N.N.P., Lam, Q.V. \& Huynh, T.D. 2015. Preparation of gold nanoparticles by microwave heating and application of spectroscopy to study conjugate of gold nanoparticles with antibody E. Coli O157: H7. Advances in Natural Sciences: Nanoscience and Nanotechnology 6(3): 1-6.

Noruzi, M. 2014. Biosynthesis of gold nanoparticles using plant extracts. Bioprocess and Biosystems Engineering 38(1): 1-14.

Ojea-Jiménez, I., Romero, F.M., Bastús, N.G. \& Puntes, V. 2010. Small gold nanoparticles synthesized with sodium citrate and heavy water: Insights into the reaction mechanism. Journal Physical Chemistry 114(4): 1800-1804.

Pantidos, N. \& Horsfall, L.E. 2014. Biological synthesis of metallic nanoparticles by bacteria, fungi and plants. Journal of Nanomedicine and Nanotechnology 5(5): 1-10.

Penders, J., Stolzoff, M., Hickey, D.J., Anderson, M. \& Webster, T.J. 2017. Shape-dependent antibacterial effects of noncytotoxic gold nanoparticles. International Journal of Medicine 12: 2457-2468.

Pernodet, N., Fang, X., Sun, Y., Bakhtina, A., Ramakrishnan, A., Sokolov, J., Ulman, A. \& Rafailovich, M. 2006. Adverse effects of citrate/gold nanoparticles on human dermal fibroblasts. Small 2(6): 766-777.

Philip, D. 2010. Rapid green synthesis of spherical gold nanoparticles using Mangifera indica leaf. Spectrochimica Acta Part A: Molecular and Biomolecular Spectroscopy 77(4): 807-810

Rajan, A., Rajan, A.R. \& Philip, D.O. 2017. Elettaria cardamomum seed mediated rapid synthesis of gold nanoparticles and its biological activities. Open Nano 2: 1-8.

Rao, Y., Inwati, G.K. \& Singh, M. 2017. Green synthesis of capped gold nanoparticles and their effect on Gram-positive and Gram-negative bacteria. Future Science $O A$ 3(4): FSO239.

Said, D.A., Ali, A.M., Khayyat, M.M., Boustimi, M., Loulou, M. \& Seoudi, R. 2019. A study of the influence of plasmonic resonance of gold nanoparticle doped PEDOT: PSS on the performance of organic solar cells based on $\mathrm{CuPc} / \mathrm{C} 60$ Heliyon 5(11): e02675.

Shahzadi, S., Zafar, N. \& Sharif, R. 2018. Antibacterial Activity of Metallic Nanoparticles: Bacterial Pathogenesis and Antibacterial Control. London: IntechOpen.

Shankar, S.S., Rai, A., Ahmad, A. \& Sastry, M. 2004. Rapid synthesis of $\mathrm{Au}, \mathrm{Ag}$, and bimetallic Au Core-Ag shell nanoparticles using Neem (Azadirachta indica) leaf broth. Journal of Colloid and Interface Science 275(2): 496-502.

Sulaiman, G.M., Mohammed, W.H., Marzoog, T.R., Al-Amiery, A.A.A., Kadhum, A.A.H. \& Mohamad, A.B. 2013. Green synthesis, antimicrobial and cytotoxic effects of silver nanoparticles using Eucalyptus chapmaniana leaves extract. Asian Pacific Journal of Tropical Biomedicine 3(1): 58-63.

Song, J.Y., Jang, H.K. \& Kim, B.S. 2009. Biological synthesis of gold nanoparticles using Magnolia kobus and Diopyros kaki leaf extracts. Process BioChemistry 44(10): 1133-1138.

Sykes, J.E. \& Rankin, S.C. 2014. Isolation and Identification of Aerobic and Anaerobic Bacteria: Canine and Feline Infectious Diseases. California: Elsevier Inc. 
Vijayakumar, S. \& Ganesan, S. 2012. In vitro cytotoxicity assay on gold nanoparticles with different stabilizing agents. Journal of Nanomaterials 2012: 1-9.

Wagers, K., Chui, T. \& Adem, S. 2014. Effect of pH on the stability of gold nanoparticles and their application for melanine detection in infant formula. Journal of Applied Chemistry 7(8): 15-20.

Wali, M., Sajjad, A.S., Sumaira, S., Muhammad, N., Safia, H. \& Muhammad, J. 2017. Green synthesis of gold nanoparticles and their characterizations using plant extract of Papaver somniferum. Nano Science Nano Technology 11(2): 1-8.

Wang, Y., Pitto-Barry, A., Habtemariam, A., Romero-Canelon, I., Sadler, P.J. \& Barry, N.P.E. 2016. Nanoparticles of chitosan conjugated to organo-ruthenium complexes. Inorganic Chemistry Frontier 3(8): 1058-1064.

Ye, W., Leung, M.F., Xin, J., Kwong, T.L., Lee, D.K.L. \& Li, P.J.P. 2005. Novel core-shell particles with poly (N-Butyl Acrylate) cores and chitosan shells as an antibacterial coating for textiles. Polymer 46(23): 10538-10543.

Zabetakis, K., Ghann, W.E., Kumar, S. \& Daniel, M.C. 2012. Effect of high gold salt concentrations on the size and polydispersity of gold nanoparticles prepared by an extended Turkevich-Frens Method. Gold Bulletine 45(4): 203-211.

Zhao, L., Jiang, D., Cai, Y., Ji, X., Xie, R. \& Yang, W. 2012. Tuning the size of gold nanoparticles in the citrate reduction by chloride ions. Nanoscale 4(16): 5071-5076.

Zhou, Y., Kong, Y., Kundu, S., Cirillo, J.D. \& Liang, H. 2012. Antibacterial activities of gold and silver nanoparticles against Escherichia coli and Bacillus calmette-guérin. Journal of Nanobiotechnology 10(1): 19.

Zhuang, Y., Liu, L., Wu, X., Tian, Y., Zhou, X., Xu, S., Xie, Z. \& Ma, Y. 2018. Size and shape effect of gold nanoparticles in 'Far-Field' surface plasmon resonance. Particle and Particle System Characterization 36(1800077): 1-8.
Zuber, A., Purdey, M., Schartner, E., Forbes, C., van der Hoek, B., Giles, D., Abell, A., Monro, T. \& Ebendorff-Heidepriem, H. 2016. Detection of gold nanoparticles with different sizes using absorption and fluorescence based method. Sensors and Actuators B: Chemical 227: 117-127.

Ahmad Yasser Hamdi Nor Azlan, Haliza Katas* \& Nur Qaisara Jalluddin

Centre for Drug Delivery Research

Faculty of Pharmacy

Universiti Kebangsaan Malaysia

Jalan Raja Muda Abdul Aziz

50300 Kuala Lumpur, Federal Territory

Malaysia

Ahmad Yasser Hamdi Nor Azlan

Faculty of Pharmacy and Health Sciences

Universiti Kuala Lumpur (Royal College of Medicine Perak)

3, Jalan Greentown

30450 Ipoh, Perak Darul Ridzuan

Malaysia

Mohd Fauzi Mh Busra

Tissue Engineering Centre

UKM Medical Centre

56000 Cheras, Kuala Lumpur, Federal Territory

Malaysia

*Corresponding author; email: haliza.katas@ukm.edu.my

Received: 18 January 2020

Accepted: 3 March 2020 